\begin{tabular}{|c|c|c|}
\hline & JSM (9) (1) & \\
\hline & JURNAL SENI MUSIK & \\
\hline & https://journal.unnes.ac.id/sju/index.php/jsm/index & \\
\hline
\end{tabular}

\title{
BINA VOKALIA LEARNING AS EXTRACURRICULAR ACTIVITIES IN THE INTEGRATED EARLY CHILDHOOD EDUCATION (PAUD) OF SALATIGA CHILDREN CENTER
}

\author{
Irfanda Rizki Harmono Sejati \\ Departement of Dance, Drama and Music Universitas Negeri Semarang, Indonesia
}

\begin{abstract}
Article Info
Abstract

Received Februari 2020

Approved March 2020

Published June 2020

The process of learning in early childhood education and kindergarten is never apart from musical activities, although it is mostly just singing and dancing. Singing is one of the learning activities that is carried out daily from beginning of class to the end of class. Integrated PAUD Satya Wacana Children Center Salatiga provides a form of extracurricular Bina Vokalia at school to support learning, improve and develop student talent in singing. Vocal teaching of children is definitely different than adults, the delivery of the song material should be interesting to learners and in

Keywords:

Bina vokalia, learning, vocal, kindergarten teaching the child's vocal techniques is need patience and technique. In view of today's modern times, many parents are increasingly giving their children activities outside school, especially music. Integrated PAUD Satya Wacana Children Center provides a vocal building learning facility that might develop a child's talent for music. The problem considered in the study is "how the learning process of Bina Vokalia and how the obstacles and solutions to delivering vocal materials in integrated PAUD Satya Wacana Children Center"
\end{abstract}

The study employs qualitative research methods with descriptive exposure. Research subjects are students and teachers of integrated PAUD Satya Wacana Children Center salatiga. Data collection results with observation techniques, interviews, documentation and data analysis. Data analysis techniques divide into three phases that are data reduction, data presentation, and conclusions. The results of the interviews and observations already collected include the documentation, pictures, photographs, field notes, personal notes, and other documents after studied and researched than reduced to an abstraction.

As the results of research, researchers concluded that the Bina Vokalia PAUD activities could help students develop singing skills early on, not only good vocal techniques but training children to be bolder and more confident in the activities organized by the foundation. The advice is that music teachers should not be absent too often, requiring an additional event of school in order to make children more active and creative. It is necessary to increase the practice time and musical facilities so the children do not become bored prematurely. 


\section{INTRODUCING}

Music became one of the educational studies. Education itself is defined as a conscious and deliberate effort to change the behavior of both individuals or groups to enlarge man through teaching and training (sugihartono et al, 2007: 3). While the intent of music is a branch of the art, a work that reveals thoughts and feelings through musical elements such as melody, harmony, rhythm. According to Djohan (2009: 235) music education is essential for learners to develop cognitive and motor perceptions, it can also help students to create and express themselves. Music study for child that started early can stimulate a child's brain to learn everything by means of tones, rhythmic patterns, and elements found in music. Music not only provides a social interaction but also produces the opposite of the potential for action and interaction. Music is believed to have excellence, especially for children of intellectual, motor, and cognitive development and language skills (Djohan, 2009: 45). The influence and benefits of learning music are great, especially for children. Therefore, many parents are very supportive of their children's learning to make music at an early age. The value of the art of music is to help one's intelligence, so it grows the creative thinking and learning (Djohan, 2009: 170).

The education of music in schools is intended to educate students in the field of music and also to complement education in addition to other sciences. According to Haryadi (1977: 4) music education is intended for the learner to have aesthetic sensitivity especially in regard to sound, also for the learner to have positive values for his disposition, attitude and behavior. As to the purpose of the music education, the material given is adapted to the world of children having, a love of parents, a reverence for teachers by using simple musical elements, melodies, and harmonies.

According to purpose and concern for the development of a child's soul in his preschool-age age (4 to 6 years old), so implementation of education in kindergarten follows the principles of playing while learning or learning while playing. In this context various areas of development are taught by combining into one complete learning activity program. The learning program includes: (1) the habituation which is consist of of moral, religious and social development, emotional, and independence; and (2) basic abilities which consist of the areas of language development, cognitive, physical / motor, and art.

Music studies in PAUD and kindergarten is a required daily activitiy. Most in the PAUD and kindergarten there are musical studies. Music study is part of the curriculum that the IGTKI group has organized. The range of musical learning materials includes vocal and musical playing.

Researchers have observed integrated PAUD Satya Wacana Children Center in Salatiga. Integrated PAUD is a laboratory school part of Satya Wacana Christian University foundation. This integrated PAUD has several annual agendas, such as Christmas, Easter, dies natalis and other performing arts. To support the activities, the school provides activities for students to support the student talents and abilities such as dance, coloring art, and music. One of the musical arts activities is the learning of the Bina Vokalia as an extracurricular activity to support competencies and musical talent.

Through the teaching of the Bina Vokalia students are not only taught vocal and singing techniques but learned to be courageous and confident in social, can active and creative in all things. Through vocal learning the student also learned to write and read, since the study in PAUD demanding for the student especially in the B class were already able to write and read. Bina Vokalia make students not become bored in learning to write and read is one of their method. Based on the background above, the writer feels interested to raise the earning Process of Bina Vokalia as extracurricular activity in Satya Wacana Children Center, because through Bina Vokalia learning students 
can better appreciate their talents in music and form confidence for children. Through vocational learning, students can also develop ideas, conversations and imagination while being able to interact and respond to environmental influences.

\section{MATERIAL AND METHOD}

Bina Vokalia Learning Study as an extracurricular activity in the Integrated PAUD Satya Wacana Children Center Salatiga, researchers used qualitative research methods. In general, the research method used is qualitative with descriptive and interpretative exposure using qualitative data. That is, in qualitative research a researcher must be able to explore all those who can be trusted with the information he knows and does not cause contradictions with the interpretations presented

Limitation of the problem in this study is based on qualitative data and a conclusion. While the data is in the form of an explanation, description and a real illustration of the subject. Data collection techniques used in this study were observation, interviews and documentation.

a. Observation

In this research, the observation technique applied was participant observation. The researcher is directly became part of the learning of Bina Vokalia. The researcher also provided music material. Observation is used as a complement to help get more accurate data from the interview. In this research, things that will be observed include the learning process, the constraints and solutions during the learning process to the performance of formation of the vocals itself. With observation allows flexibility, reality, openness of data, and clarity in capturing the phenomena that will be studied, for that carefulness and accuracy of observation is needed.

b. Interview

Interview is conversation with a specific purpose (Moleong, 2000). The conversation was carried out by two participants between the interviewer who gave a question and the interviewee who answered the question. The interview is carried out using a set of questions that have been systematically prepared for each respondent. In this study who became as an informant (interviewee) is the Principal and Music Teacher of PAUD Integrated Satya Wacana Children Center Salatiga

c. Documentation

Documentation technique is the technique of collecting data about variable things in the form of notes, transcripts, books, newspapers, magazines, inscriptions, minutes, leggers, agendas, and so on (Arikunto, 1992: 236). This technique is done to obtain secondary data in order to complete data that has not been obtained through observation and interview techniques. Then the results of this documentation are arranged in such a way as secondary data that is used to supplement the primary data from interviews and observations.

\section{RESULT AND DISCUSSION}

Bina Vokalia is one place for a child to develop one of the talents, namely music. In addition to getting other science lessons, students are required to be able to learn to create creativity, taste, work, and intention gained through direct experience involved in playing music. In Bina Vokalia activities, all students cannot be selfish, all students will learn how to collaborate and be responsible with themselves while attending Bina Vokalia learning according to what is taught by the teacher.

In the learning of Bina Vokalia at the integrated PAUD Satya Wacana Children Center, Salatiga uses several techniques in its teaching. There are special teachers who are experts and professionals in the field of music, especially in training the choir. Practice classes are conducted twice a week and the techniques taught by teachers to children are kind of imitating methods. In this case children are also not free from the practice of correct vocal techniques.

In phonetics, a vowel is a sound in spoken language characterized by an open vocal cords so that no air pressure accumulates above the glottis. Vowels contrast with 
consonants characterized by the closure of one or more articulation points along the suata cavity. A vocal is seen as syllabic, an open sound that is similar to vocal but not syllabic is called semivocal.

In this chapter, the results of the study obtained at the integrated Satya Wacana Children Center in Salatiga will be explained. Supporting data for research results obtained through interviews and through library research. In addition it is also obtained through observation and documentation during the extracurricular learning process of Bina Vokalia at school. Observations carried out on kindergarten teachers, vocal teachers and students together at the time of the extracurricular activities of Bina Vokalia. The results of extracurricular Bina Vokalia, consisting of: Material used in Bina Vokalia extracurricular, children's vocal technique training, factors that support extracurricular Bina Vokalia and the constraints and solutions during extracurricular Bina Vokalia.

The training process is expected to take place effectively and efficiently with a time that has been determined by the school, from the explanation of the material to vocal training techniques. Before practice begins, the teacher first motivates students about the correct singing techniques.

In this study, an explanation of diaphragmatic breathing is given, especially in the vocal technique for early childhood. The following is a description of the extracurricular activities of Bina Vokalia in the Integrated Satya Wacana Children Center Salatiga.

In vocal learning, the teacher gives examples of techniques with correct body position, breathing techniques.

a. Posture

Correct posture and stand up straight.

b. Respiratory technique

Respiratory used is diaphragmatic breathing. Air that is inserted through the nose is directly flowed into the abdominal cavities and issued bit by bit. Good breath regulation is closely related to proper expression or interpretation.

The first step in learning, after the teacher gives an example of how to breathe the diaphragm is followed by producing a unanimous voice. In order to get a clear tone start, you need to practice warming up with a tone with the articulation "ha". The teacher gives examples on the scales $\mathrm{C}, \mathrm{G}$, and $\mathrm{A}$ by singing long notes (2 tap up and down) on each note then proceed to practice the rhythm pattern with the "hu" intonation repeatedly.

After warming up the scales then the material to the song will be taught as a song titled We Believe and Bangun Tidur. In the song material, articulation learning is taught in singing English songs with Indonesian songs.

Some of the activities that have been carried out are in the context of filling out school and foundation activities such as Christmas, Easter, open house and art performances, Graduation and several choir competitions in the kindergarten category at Unika Soegijapranata Semarang.

At the time of going to the choral festival, the children are asked to take part in intense training to get maximum results. Some of the exercises include correct singing techniques, good tone colors and don't use a lot of head voices for the category of early childhood.

Constraints and Solutions During the Learning Process of Vocational Development

In every learning or activity in undergoing a process, it certainly cannot be separated from the obstacles encountered. Bina Vokalia TK PAUD integrated Satya Wacana Children Center Salatiga already has very supportive facilities such as music classes which are very adequate because it is wide enough to practice choirs equipped with keyboards, soundsystem, AC and whiteboard. But some obstacles are technical problems that are actually experienced by some students who have high learning enthusiasm in playing musical instruments as the first is some students who have difficulty when regulating breathing especially in vocal technique training, moreover the mood and soul of kindergarten children who often change during the vocal learning process. 
In the choir formation, some obstacles such as students that singing one of the song forget the lyrics in the particular song, there are some students who have just learned vocals during choir learning and still find the difficult to imitate rhythmic, lyrics and melodies in the song. There are even some students who often do not admission due to illness so the child becomes late in receiving new material and there are several possibilities for the teacher to give the material too quickly. So that students felt take a long time in receiving the material.

According to observations, the existing constraints are only technical problems because the facilities are already more than enough that has been provided by the school. They need for additional facilities but not so much.

The solution that can be offered is the teacher and school must strongly support and motivate all student activities, both inside and outside the school. Give a lot of appreciation for students who take extracurricular activities. Parent, teacher, and school must patiently teach every detail of kindergarten students who experience obstacles during the learning process. Because each child has very different catching abilities in absorbing the new knowledge, especially in learning music.

\section{CONCLUSION}

Based on the results of research and observations, it can be concluded that the application of the soul of conservation from an early age, especially the humanist pillar. It can be realized through artistic activities, in particular is the extracurricular activities of Bina Vokalia. Bina Vokalia is a form of choir with vocal types of one voice or mix, different sound characters. With singers who have different characters and personalities and put together in a community to build a harmony of songs that have been arranged into a choir.

During the learning process of vocational development at the Integrated PAUD Satya Wacana, the students not only gained good singing music skills, but also learned about character education. In addition, it is the knowledge of conservation values that students get during participating in Bina Vokalia activities. Choir also teaches students to be independent, creative and to have good personalities.

The embodiment of 11 conservation character values that must be possessed by students have emerged when the initial process of Bina Vokalia training begins, namely religious attitude, honest attitude, intelligent, fair and have a high responsibility, caring each others which is manifested by an attitude of willingness to work together, a spirit of high tolerance, have a democratic mindset which means not selfish, also the love of the motherland by always upholding national song to be developed in a musical performance, making innovations and new creations by developing regional songs to packaged into a choir.

\section{REFERENCE}

Arikunto, Suharsini. 1992. Prosedur Penelitian Suatu Pendekatan Praktek. Jakarta: Rineka Cipta.

Salim, Djohan. 2009. Psikologi Musik. Yogyakarta: Best Publisher.

Haryadi, dkk. 1977. Metode Pendidikan Seni Musik Untuk Sekolah Dasar dan Sekolah Menengah Pertama. Jakarta: Departemen Pendidikan dan Kebudayaan.

Moleong, Lexi J. 2000. Metodologi Penelitian Kualitatif. Surakarta: UNS Press.

Sugihartono, dkk. 2007. Psikologi Pendidikan. Yogyakarta: UNY Press. 